Article

\title{
Social Farming: Heterogeneity in Social and Agricultural Relationships
}

\author{
Angela Genova *, Martina Maccaroni and Elena Viganò \\ Department of Economics, Society, Politics, University of Urbino Carlo Bo, 61029 Urbino, Italy; \\ m.maccaroni@campus.uniurb.it (M.M.); elena.vigano@uniurb.it (E.V.) \\ * Correspondence: angela.genova@uniurb.it
}

Received: 30 April 2020; Accepted: 10 June 2020; Published: 12 June 2020

check for updates

\begin{abstract}
Social farming (SF) has emerged as a social innovation practice shaping heterogeneous approaches and results. This study discusses the complexity of SF policy and practices, and it is led by the main hypothesis that the relationship between agricultural and social dimensions might be very heterogeneous, not only in different national contexts but also within the same national and local level. SF policy and practices are investigated testing the hypothesis of three main different modalities of interaction according to how the social and the agricultural perspectives interact. In the first, social target is not involved in the production system of the farm and the farm is the context where actions and measures of a social nature take place. In the second type of interaction, the farm employs the beneficiaries in some of its production activities collaborating with the social services. The third is where the farm organizes its activities to actively employ targeted people to enhance their social inclusion and integration in the community. Italian SF policy and practices are analyzed as case study, through the lens of sociological critical discourse analysis regarding the regional regulatory documents, and interviews for local case studies. The results of the study show that SF policy and practices might be very heterogeneous also within the same national and local level, outlining different hybridization of social and agriculture actions that can be properly analyzed through the three SF model proposal. This study contributes to the broader debate on the various dimensions of sustainability, suggesting the need for further research on the efficiency of SF as local development model sustainable in economic, social and environmental terms.
\end{abstract}

Keywords: regional regulations; critical discourse analysis; social innovation; multifunctional agriculture; diversification; organic agriculture

\section{Introduction}

Social farming (SF) is a phenomenon rich in innovative experiences [1], characterized by multiple forms of relationships (including extra-market) between different stakeholders. SF is a practical implementation of the concepts of multifunctional agriculture and diversification [2-5]; it is coherent with the promotion of local development models that are sustainable in economic, social and environmental terms [6-8]. Moreover, it has been developed through an increasing awareness of the tangible and intangible resources developed by agriculture. The agricultural context is characterized by the development of productive commodities as well as specific relations between people and with the environment, providing a framework with the potential of responding to the social needs of communities, especially in fragile rural areas. In recent decades, neoliberal reforms have deprived fragile rural areas of most of their social and community services due to cost containment policies [9-11]. SF could also provide social or educational services to tackle social exclusion for the disadvantaged or those with disabilities [12,13]. 
Furthermore, SF offers an important opportunity to create income and employment for many agricultural enterprises capable of halting the exodus towards urban areas which has been going on for several decades now, with an associated loss of production activities [14]. In rural areas, the orographic and pedoclimatic context, as well as the structural characteristics of many agricultural firms reduce the likelihood of achieving adequate competitiveness in producing commodities. SF thus represents a form of diversification of farm activities which offers an opportunity to define new development strategies for small- and medium-sized farms and thereby increases their chances of survival [15-17].

In Europe, the first SF activities were realized in the 1960s, then SF has developed according to different national paths, shaping two main different models: the Northern European specialized model and the Mediterranean Communitarian model of Social Farming [18-20]. Differences concern the main protagonists as well as the relationship between them. In Italy and France, SF is mainly organized by third sector organizations, while in Belgium by the private sector, and in Germany, it has been institutionalized. Moreover, in Netherlands, it is mainly family-based activities, in Ireland or Italy it is community-based and in Germany, is it professionally-based [21].

In the last decade, SF has been part of the European policy agenda for rural development [22], and despite the fact that it is still too early to assess the impact of the past and ongoing investments, it might be assumed that they have represented a relevant opportunity for SF development in Europe [23]. SF has emerged as a social innovation practice [18] characterized by a bottom-up process shaping heterogeneous approaches, and results in creating viable and sustainable rural and peri-urban areas according to a social-ecological perspective [24]. It has also been named with different labels such as care farming or green care, thus underlining the aim to combine caring for people with caring for land [25]. The interaction between agriculture practices and care provision shapes an area of hybrid practices [26] and transdisciplinary research [27] that has been conceptualized and articulated as "connective agriculture" by Leck, Evans and Upton [28].

Despite several studies on different national experiences in Europe $[25,28-33]$, there is a lack of development in the theoretical framework for SF analysis. Therefore, this study discusses the complexity of SF policy and practices, and it is led by the main hypothesis that the relationship between agricultural and social dimensions might be very heterogeneous, not only in different national contexts, as it has been argued in previous studies, but also within the same national and local level. Therefore, this article investigates SF policy and practices at national and regional level, focusing on Italy as a national case study, to contribute to investigating the hybrid characteristics of SF policy and practices, testing the hypothesis of three main modalities of interaction according to how the social and the agricultural perspectives interact and are integrated [9]. The first involves interaction between agriculture and social services which involves simply sharing some designated areas without actively employing targeted people in the farming activity: the social aspects do not interfere with the main production activity, but the farm is the context where actions and measures of a social nature take place. In the second type of interaction, the farm employs the beneficiaries in some of its production activities collaborating with the social services. The third is where the farm organizes its activities to actively employ disadvantaged people to enhance their social inclusion and integration in the community.

In Italy, despite the increasing interests concerning SF development, there is a lack of systematic data on SF practices. In the attempt to give an official dimension to social farming, the Italian regions have envisaged in their laws, the display of lists of the recognized social farming operators; nevertheless, its implementation is still ongoing. The regional lists are consultable online, and so far, only 202 experiences have been collected and are located in only eight Regions. The information gap about social farming is quite huge, since social farming is widespread within the Italian territory. In the last decade, different associations and experts have been trying to give a description of social farming phenomenon-mainly from a qualitative point of view-to bridge the information gap. A recent attempt to give a quantitative dimension to social farming was carried out within the Rete Rurale Nazionale project in 2017 through a report about social farming in Italy [13]. Within this study, it was possible to identify more than 1000 social farming experiences located within the Italian territory. 
However, the number of social farming operators is most likely to be higher and more studies should be carried out at a national level to obtain a clearer picture of social farming.

The Italian case has already been broadly studied and, therefore, some of the main characteristics of SF in Italy have been discussed, such as some aspects of regional differences as well as innovation [34-37]. This represents a point of strength of this study because it is based on an updated and deep analysis of national and regional policy contexts as well as local practices, and has pushed forward the comparative analysis and suggested a theoretical framework of analysis that might be of interest to a much broader and international audience.

\section{Materials and Methods}

\subsection{Social Farming Policy Analysis at a Regional Level}

In Italy, at a national level, the main regulatory context for SF is represented by National Law No. 141 of 2015. However, institutional autonomy has pushed several regions into adopting specific and heterogeneous regulatory contexts to support SF [38]. This study develops a comparative enquiry into those regional regulations, focusing on policy targets, promoted activities and supporting tools through a sociological and critical discourse analysis approach [39]. According to critical discourse analysis, social realities have a reflective character and, consequently, the way people see, represent, interpret and conceptualize them is an integral part of reality itself. Any social event or practice is conditioned by conceptualization proposed at the political-institutional level [39], therefore, it becomes important to focus on the way social agriculture has been treated in the regional regulatory documents; that is to say, how its meanings have been constructed and, based on these, how it then acted on the region.

In particular, this analysis traces the transdisciplinary aspects of a social, cultural, historical, institutional and political nature, on the way to creating an identity for social agriculture in the Italian regions. Specific contexts construct distinct meanings that have the potential for developing very different policies and actions [40], even in contiguous territories.

The analysis of the policy context focused on the core regional regulatory framework documents. The following aspects were investigated:

- the timing of the main regulatory policy for SF at a regional level;

- the main public authority involved, and the central framework within which SF policy has been developed at a regional level;

- the core activities to be carried out, those able to carry out SF, and the support measures envisaged by the regional laws.

\subsection{Social Farming Practices in the Case Study of the Marche Region}

To investigate SF practices in Italy, this study focuses on SF practices in the Marche case study. These are examined through primary and qualitative data, focusing on the views of 7 farmers. The Marche region has been selected because it counts 50 out of the 202 social farming operators officially collected in the regional lists; moreover, being in the centre of Italy, it is likely to represent Italian heterogeneity, merging some features of the more economically developed regions in the north and some elements of the southern regions [41]. Data on productive models contribute to an investigation into the ecological transition of enterprises from industrial to organic production. The specific features of innovative interaction between the agricultural and social sectors are deeply investigated.

Data on SF practices in the Marche region were collected through semi-structured interviews with 7 farmers in 2019, updating some of the data previously collected. To select cases, we chose to adopt the three main criteria identified by [42]: convenience, access and geographic proximity. Specifically, we used the multiple case study method with a deliberate sampling technique to select information-rich cases [43]. Regarding data analysis, we adopted Miles and Huberman's three-step approach [44], consisting of data reduction, data display, and verification. 
The list of 50 regional social farming experiences in the Marche EROAS (Elenco Regionale degli Operatori Agricoltura Sociale) was used as a first database to identify the possible social farming operators active in the region to interview. In addition to this, a web-based research was carried out to extend the analysis to those experiences not officially recognized. The list used to carry out the analysis then collected both unrecognized and recognized social farming activities. The list was mainly composed of social cooperatives and agricultural firms. They were then contacted by email and asked if they were willing to be interviewed to share their farming experiences and discuss SF. Seven social farming operators gave their consent to be contacted by phone. The analyzed cluster was composed of 3 social cooperatives and 4 agricultural firms. The interviews lasted about $30 \mathrm{~min}$. Questions were aimed at gathering data on the characteristics of the farms, and their knowledge or direct experience of SF.

\section{Results}

\subsection{Heterogeneous Social Farming Regional Regulatory Frameworks}

In respect of social farming, Italian Law No. 141/2015 states in Article 3 that the regions are responsible for regulating SF activities by defining the criteria for recognition, along with the implementation and development procedures for officially identifying SF operators and placing them on regional lists [45]. The Italian regions have played a fundamental role in the spread and development of social farming activities by recognizing more quickly than national institutions that SF is an innovative solution to real emerging problems facing society and the agricultural sector. Social agriculture has even been seen as an innovative tool for promoting and increasing the wellbeing of the disadvantaged by providing activities and services that meet the emerging needs of the community in rural areas. Nevertheless, analysis of Italian regulatory context shows that SF has been part of the agriculture and rural development policy agenda, while it has been mainly absent in the national and regional social and welfare policies [11]. Therefore, the Italian SF regulatory framework is dominated by the farmers' point of view, while the citizens' perspective, as people requiring social services support, has never been properly contextualized in the local social services contexts. SF is, in fact, mostly absent in the social policy documents at national or regional level [11]. Moreover, after the National Law has been passed, the implementing regulatory acts have still to be fully defined, also with regard to the gray boundary between social and farming activities.

\subsubsection{Different Timeframes and Contexts in SF Regional Policies}

In Italy, several regions started approving legislative measures to facilitate SF dissemination and benefits before the national institutions. Social Farming projects have found it easier to spread where there have been legislative measures integrating agricultural, social and health policies with the aim of guaranteeing extensive local services and income for farms. The presence of SF in the 2007-2013 Rural Development Plans (RDPs) furthered the trend initiated by the regions. From this evidence, we can see how the regional legislative processes have resulted in a heterogeneous and fragmented situation, since contexts and timeframes differed from region to region, and the authorities in charge also had different knowledge of the phenomenon. On the one hand, some regions made ad hoc rules (e.g., Abruzzo, Campania, Liguria, the Veneto, Molise, Basilicata and Tuscany); on the other hand, some placed SF within the rules on agritourism and/or multifunctionality (Lombardy, Trentino, Friuli-Venezia Giulia, Marche, Umbria, Calabria, Sardinia) followed, in some cases (e.g., the Marche), by the preparation of guidelines or provisions for the development of specific experiences $[38,46]$.

Table 1 summarizes the regional laws regulating social farming.

As it can be noted from the table above, all the Italian regions have approved legislative measures to regulate social farming activities except for the Valle d'Aosta. However, this absence does not indicate a lack of regional support for SF activities operating within its territory; SF appears in Measure 16 'co-operation' of the 2014-2020 RDP, and Law no. 141 of 2015 gives the criteria for obtaining funds. 
Table 1. Italian regional laws regulating Social Farming.

\begin{tabular}{|c|c|c|}
\hline Region & Regulation & Title \\
\hline Abruzzo & Regional Law No. 16 of 6 July 2011 & Provisions on Social Farming \\
\hline Basilicata & Regional Law No. 53 of 17 December 2018 & Provisions on Social Farming \\
\hline Calabria & Regional Law No. 14 of 30 April 2009 & New regulations for the implementation of didactic and social activities and agritourism \\
\hline Campania & Regional Law No. 5 of 30 March 2012 & Regulations on social agriculture, social farms and social gardens and modification of Regional Law No. 11 of 7 March 1996 \\
\hline Emilia Romagna & Regional Law No. 4 of 31 March 2009 & Regulations on agritourism and multifunctionality of farms \\
\hline Friuli-Venezia Giulia & Regional Law No. 2 of 6 February 2018 & Modification of Regional Law No. 15 of 8 August 2000 and provisions on Social Farming \\
\hline Lazio & Regional Law No. 7 of 22 October 2018 & Provisions on simplification and regional development \\
\hline Liguria & Regional Law No. 36 of 21 November 2013 & Provisions on Social Farming \\
\hline Lombardy & Regional Law No. 35 of 12 December 2017 & Provisions on Social Farming \\
\hline Marche & Regional Law No. 21 of 14 November 2011 & Regional provisions on the multifunctionality of the farm and diversification in agriculture \\
\hline Molise & Regional Law No. 5 of 10 February 2014 & Provisions on Social Farming \\
\hline Piedmont & Regional Law No. 1 of 22 January 2019 & Reorganization of regulations on agriculture and rural development \\
\hline Province of Bolzano & Provincial Law No. 8 of 22 June 2018 & Social Farming \\
\hline Province of Trento & Provincial Law No. 12 of 21 July 2016 & Modification of Provincial Law on agritourism 2001 and Provincial Law on kindergarten 2002 on Social Farming \\
\hline Puglia & Regional Law No. 9 of 27 March 2018 & Provisions on Social Farming \\
\hline Sardinia & Regional Law No. 11 of 11 May 2015 & Regulation on agritourism, fishing tourism, didactic and Social Farming \\
\hline Sicily & Regional Law No. 16 of 11 August 2017 & Regional Stability Law for the year 2017-Art. 41-Social Farming \\
\hline Tuscany & Regional Law No. 24 of 26 February 2010 & Provisions on Social Farming \\
\hline Umbria & Regional Law No. 12 of 9 April 2015 & Consolidated Law on agriculture \\
\hline Veneto & Regional Law No.14 of 28 June 2013 & Provisions on Social Farming \\
\hline
\end{tabular}

Source: Elaboration on [38]. 
As indicated in Table 2, the legislative model followed by Italian regions is different according to the timeframe of approval and the legislative process involved. The majority of Italian regions regulated SF before the definition of a national regulation framework. Two regions (Emilia-Romagna and Calabria) approved a law on social farming as an opportunity for promoting the diversification of agricultural activities as far back as in 2009. This model was then pursued by the Marche, Campania and Sardinia, which inserted SF into wider laws on multifunctionality, diversification of agricultural activities and agritourism. Tuscany was the first region to approve a specific law on social farming allowing its spread in the territory, whilst Umbria included SF in broader regulation on agriculture.

Most regional laws (Piedmont, Province of Bolzano, Friuli-Venezia Giulia, Puglia, Basilicata and Sicily) approved after Law no. 141 of 2015 are in full harmony with what is stated in that law. Lombardy has regulated social farming in great detail, taking its cue, however, from Law no. 141 of 2015. Lazio has not properly approved a specific law on SF; with the approval of Regional Law no. 7 of 2018, the region added social farming as a tool for diversification of agricultural activities in accordance with the National Law [38].

With a focus on the Marche, Regional Law No. 21 of 14 November 2011, Article 2, Regional provisions on the multifunctionality of the farm and diversification in agriculture, considers SF as an activity within agriculture, in line with Article 2135 of the Italian Civil Code, and Decree Law No. 228 of 2001 Orientation and modernization of the agricultural sector, in accordance with Article 7 of the Law of 5 March 2001, No. 57. In other words, SF is seen as a form of hospitality, like agritourism, integrated into the company's activities. A crucial point of the legislation is the balance of activities (Article 26), which establishes the need to maintain agricultural activity as the core activity. This is achieved when the time-work ratio attributed to it is higher than that foreseen for SF activity and "when the personnel hired with a non-agricultural qualification is numerically inferior to the staff normally employed for the ordinary management and organization of the primary activity." For social cooperatives, the balance must be established exclusively in the context of their agricultural activity. This shows a clear imbalance between agricultural and social activities in favor of the first, not only in farms but also in social cooperatives involved in SF activities. The regional regulations, in fact, consider SF as an activity mainly connected to agriculture in promoting the diversification and multifunctionality of farms, more than social activities being part of the social services network. Moreover, the issue is very complex and controversial, and the regulatory acts for its implementation is still to be defined in Italy.

\subsubsection{Activities, Personnel and Support in SF Regional Policies}

To deeply investigate SF regional regulation, in this paragraph, the different laws have been compared and analyzed to illuminate similarities and differences. In particular, the main activities that can be conducted, the personnel permitted to carry out $\mathrm{SF}$, and the support measures envisaged by the regional laws have been compared. 
Table 2. Characteristics of regional regulations.

\begin{tabular}{|c|c|c|c|c|c|c|}
\hline \multirow[b]{3}{*}{ Region } & \multicolumn{2}{|c|}{ Period of Approval } & \multicolumn{4}{|c|}{ Article of Social Farming } \\
\hline & \multirow[b]{2}{*}{$\begin{array}{l}\text { Before National Law } \\
\text { No. } 141 \text { of } 2015\end{array}$} & \multirow[b]{2}{*}{$\begin{array}{l}\text { After National Law } \\
\text { No. } 141 \text { of } 2015\end{array}$} & \multirow[b]{2}{*}{$\begin{array}{l}\text { Specific Provision } \\
\text { for SF Regulation }\end{array}$} & \multicolumn{3}{|c|}{ SF insertion within Other Regional Laws } \\
\hline & & & & $\begin{array}{c}\text { In Regulations on Agricultural } \\
\text { Multifunctionality/Diversification }\end{array}$ & $\begin{array}{c}\text { In Broader Regulations on } \\
\text { Agriculture or Rural Development }\end{array}$ & $\begin{array}{l}\text { In the Agricultural } \\
\text { Stability Law }\end{array}$ \\
\hline Abruzzo & $\mathrm{x}$ & & $\mathrm{x}$ & & & \\
\hline Basilicata & & $\mathrm{x}$ & $\mathrm{x}$ & & & \\
\hline Calabria & $\mathrm{x}$ & & & $\mathrm{x}$ & & \\
\hline Campania & $\mathrm{x}$ & & & $\mathrm{x}$ & & \\
\hline Emilia-Romagna & $\mathrm{x}$ & & & $\mathrm{x}$ & & \\
\hline $\begin{array}{l}\text { Friuli-Venezia } \\
\text { Giulia }\end{array}$ & & $\mathrm{x}$ & & $\mathrm{x}$ & $\mathrm{x}$ & \\
\hline Lazio & & $\mathrm{x}$ & & $\mathrm{x}$ & $\mathrm{x}$ & \\
\hline Liguria & $\mathrm{x}$ & & $\mathrm{x}$ & & $\mathrm{x}$ & \\
\hline Lombardy & & $\mathrm{x}$ & $\mathrm{x}$ & & & \\
\hline Marche & $\mathrm{x}$ & & & $\mathrm{x}$ & & \\
\hline Molise & $\mathrm{x}$ & & $\mathrm{x}$ & & & \\
\hline Piedmont & & $\mathrm{x}$ & & & $\mathrm{x}$ & \\
\hline $\begin{array}{l}\text { Province of } \\
\text { Bolzano }\end{array}$ & & $\mathrm{x}$ & $\mathrm{x}$ & & & \\
\hline Province of & & & & & & \\
\hline Trento & & $\mathrm{x}$ & & $\mathrm{x}$ & & \\
\hline Puglia & & $\mathrm{x}$ & $\mathrm{x}$ & & & \\
\hline Sardinia & $\mathrm{x}$ & & & $\mathrm{x}$ & & \\
\hline Sicily & & $\mathrm{x}$ & & & & $\mathrm{x}$ \\
\hline Tuscany & $\mathrm{x}$ & & $\mathrm{x}$ & & $\mathrm{x}$ & \\
\hline Umbria & $\mathrm{x}$ & & & & $\mathrm{x}$ & \\
\hline Veneto & $\mathrm{x}$ & & $\mathrm{x}$ & & & \\
\hline
\end{tabular}


Analysis of the regional regulatory context shows a very heterogeneous scenario within which SF concerns rural child care (Marche and Lombardy regions) and rehabilitative activities for people with health problems, also including pet therapy and natural medicine. Social inclusion is also associated with SF activities with specific references to cohousing practices, social housing and environmental sustainability. Nevertheless, the central regions have not specified, in greater detail, SF activities compared to northern and southern regions. Tuscany, for example, identifies just two macro-categories: socio-labor insertion and educational assistance and/or training activities. Furthermore, with reference to the implementation of SF activities, the region of Lombardy identifies two different types of social farming, namely, the fattorie inclusive (inclusive farms), where the disadvantaged play an active part in agricultural production, thereby promoting social work inclusion, and the fattorie erogative (providing farms) where the vulnerable are beneficiaries of the services but do not participate in production [47]. In addition, the inclusive farms target their activities at prisoners on release schemes or ex-prisoners, those with drug or alcohol addictions, the mentally or physically disadvantaged and job seekers. In harmony with the provisions of the National Law, all the regions recognize, as SF providers, the so-called agricultural entrepreneur (farmer) and social cooperatives, whose income derives mainly from agricultural activity.

Another interesting element to consider concerns measures supporting SF activities (Table 3). Articles 5 and 6 of National Law No. 141 of 2015 define various incentives to support and facilitate the development of social farm activities, such as the definition of priority criteria for participation in bids to public calls for the supply of organic foods for hospitals and school canteens by defining priority criteria; the letting of public fields and plots confiscated from mafia organizations; the furthering of direct support from public bodies to promote SF activities through the organization of training courses and citizen awareness; and maintaining $5 \%$ of market stands in the local direct market for farms demonstrating that their products come from social farming activities.

The Marche and Emilia-Romagna are the only regions providing only financial support. In contrast, Tuscany and Umbria are also considering the possibility of granting regional heritage assets to social farms. Furthermore, they also define measures to increase knowledge about and marketing of agri-food products from social farms, for example, through their use in public canteens (health, school and university), promotion on short supply chains or the creation of dedicated platforms.

In particular, Liguria and Puglia promote the development of regional and district partnership desks for those interested in implementing social farming programs to establish networks.

The Province of Bolzano has the most financially concrete law, promoting a series of financial measures, such as investment in the adaptation and equipping of buildings dedicated to SF activities, help in covering the costs of assistance and healthcare services, and grants for the organization of training and updating courses.

Lombardy has also defined several measures to support social farms, such as the promotion of products derived from social agriculture in collective catering managed by public and regional bodies, and the acknowledgement of preferential criteria in the attribution of European, national and regional contributions of a financial nature. 
Table 3. Measures of support.

\begin{tabular}{|c|c|c|c|c|c|c|c|c|}
\hline \multirow[b]{2}{*}{ Regions } & \multirow[b]{2}{*}{$\begin{array}{l}\text { Not Mentioned } \\
\text { in the Law }\end{array}$} & \multicolumn{7}{|c|}{ Measures of Support } \\
\hline & & $\begin{array}{c}\text { Financial } \\
\text { Contributions }\end{array}$ & $\begin{array}{c}\text { Priority } \\
\text { Criteria in Bids }\end{array}$ & $\begin{array}{c}\text { Rental/Concession of Public } \\
\text { Fields and Land Plots } \\
\text { Confiscated from Mafia } \\
\text { Organizations }\end{array}$ & $\begin{array}{l}\text { Training } \\
\text { Courses }\end{array}$ & $\begin{array}{c}\text { Sensibilization of Citizens } \\
\text { (Raising Awareness, Sales } \\
\text { Promotion) }\end{array}$ & $\begin{array}{c}\text { Definition of Dedicated Measures in } \\
\text { the RDP-Definition of Dedicated } \\
\text { Regional Policies }\end{array}$ & $\begin{array}{l}\text { Priority Criteria or } 5 \% \text { Stands } \\
\text { at Local Direct Markets for } \\
\text { Farms Providing SF Products }\end{array}$ \\
\hline Abruzzo & & & $\mathrm{x}$ & $\mathrm{x}$ & & $\mathrm{x}$ & & \\
\hline Basilicata & & & $\mathrm{x}$ & $\mathrm{x}$ & & & $\mathrm{x}$ & \\
\hline Calabria & $x$ & & & & & & & \\
\hline Campania & $\mathrm{x}$ & & & & & & & \\
\hline Emilia-Romagna & $\mathrm{x}$ & & & & & & & \\
\hline $\begin{array}{l}\text { Friuli-Venezia } \\
\text { Giulia }\end{array}$ & & & $x$ & $\mathrm{x}$ & & $\mathrm{x}$ & & $\mathrm{x}$ \\
\hline Lazio & $\mathrm{x}$ & & & & & & & \\
\hline Liguria & & & $\mathrm{x}$ & $\mathrm{x}$ & $\mathrm{x}$ & $\mathrm{x}$ & $\mathrm{x}$ & \\
\hline Lombardy & & $\mathrm{x}$ & $\mathrm{x}$ & & $\mathrm{x}$ & $\mathrm{x}$ & & $\mathrm{x}$ \\
\hline Marche & & $\mathrm{x}$ & & & & & & \\
\hline Molise & & & $x$ & $x$ & $\mathrm{x}$ & & & $x$ \\
\hline Piedmont & & $\mathrm{x}$ & & $\mathrm{x}$ & & & & \\
\hline Province & & $\mathrm{x}$ & & & & & & \\
\hline $\begin{array}{l}\text { of Bolzano } \\
\text { Province }\end{array}$ & & & & & & & & \\
\hline of Trento & & $\mathrm{x}$ & $x$ & $x$ & & $x$ & & \\
\hline Puglia & & $\mathrm{x}$ & $\mathrm{x}$ & $\mathrm{x}$ & $\mathrm{x}$ & $\mathrm{x}$ & & $\mathrm{x}$ \\
\hline Sardinia & & & & & $\mathrm{x}$ & & & \\
\hline Sicily & $\mathrm{x}$ & & & & & & & \\
\hline Tuscany & & & $\mathrm{x}$ & $\mathrm{x}$ & & $\mathrm{x}$ & & \\
\hline Umbria & & & $\mathrm{x}$ & & & $\mathrm{x}$ & & $\mathrm{x}$ \\
\hline Veneto & & $\mathrm{x}$ & $\mathrm{x}$ & $\mathrm{x}$ & $\mathrm{x}$ & $\mathrm{x}$ & & $x$ \\
\hline
\end{tabular}

$\mathrm{x}=$ yes. 


\subsection{SF Practices in a Regional Case Study}

The Marche is one of the most politically active regions in Italy with respect to social farming. In 2010, the region set the stage for the development of pilot experiences through a project called Social Rural World. The purpose was the promotion of the social nature of the farm, which provides food resources as well as social and relationship-based services able to improve the life quality of the community through the promotion of a healthy way of life and outdoor activities. The region is the promoter of dedicated projects: the Agrinido (rural child care) model; the Longevità Attiva (active longevity project) model; and the Ortoincontro (garden meeting) project.

The Agrinido model sets the characteristics for rural child care with regards to pedagogic, architectonic and farm formats in order to define quality standard [48]. The approach is rooted in the Montessori pedagogic perspective. Children's activities in farm contexts are guided by trained operators.

The Longevità Attiva (active longevity project) model aims at outlining the features of active ageing projects in rural areas, defining the quality standards that farmers have to respect in order to have access to regional funds for these projects [49]. The model defines socializing and occupational rehabilitative activities such as walking projects in rural areas, meetings with young and local community people, food education workshops and garden cultivation workshops. In addition, cohousing possibilities for older people and specific 'sensory gardens' for people with cognitive fragility are outlined.

The Ortoincontro (garden meeting) project has intended to support more sustainable life styles, fostering competitiveness of local products as well as presenting social farming possibilities to local communities [50]. However, it was funded only for a limited time.

\subsubsection{Farmer Characteristics in the Empirical Cases}

In order to better understand how SF activities are rooted in the territory of the region, a qualitative analysis of seven regional practices was carried out. The analysis is structured in three parts. The first collects the characteristics of the farms; the second focuses on a description of social farming activities; the third gathers the opinions of the interviewed SF operators with a focus on the strengths, the weaknesses, and suggestions they have to support more social farming.

The analyzed cases concern the experiences of seven agricultural firms active in the Marche region; the majority are from the Province of Pesaro Urbino (Table 4). The farms are small- and medium-sized (especially in terms of employees), but they are quite differentiated in terms of production systems and years in business (some are fairly new; others have been in business for 8-10 years). All the farms adopt organic farming methods ( 6 out of 7 are certified), thereby confirming their attention to environmental issues. In addition to agricultural production, they offer different services, such as work placement, educational and rehabilitative activities, and retailing. With respect to subscription to EROAS, the regional list of recognized SF operators working in the region's territory, five of the interviewees are listed. All the interviewees are in possession of the high school diploma; three (Farm 4, Farm 6 and Farm 7) are also university graduates.

\subsection{2. $\mathrm{SF}$ in the Empirical Cases}

All the firms have activated one or more SF projects to provide services (Table 5). Their experiences turn out to be very differentiated according to the activities carried out and the groups of people targeted by the activities. For example, the core services provided by Farm 2 revolve around three main spheres: work inclusion, education and rehabilitation. The work sphere involves the disadvantaged (e.g., those with drug addictions; ex-prisoners) and/or disabled people in the production system; this is achieved through providing training internships and job placements. The educational and didactic sphere provides activities and lectures on biodiversity and the rural world in order to sensitize and raise awareness. In this sphere, children and middle and high school teenagers are the main targets; they are taken on a path of personal growth to help them develop and strengthen eco-friendly behavior 
from the early years of their lives. An example is the Agrinido model, a kindergarten within a farm where children have daily lessons on nature and environmental protection. The rehabilitation sphere supports therapeutic services provided by public bodies by using animals and plants; direct contact with nature and animals is known to be therapeutic for people with mental and physical problems. For example, Farm 3 uses its donkeys to help rehabilitation through direct contact and care of them. Farm 1, on the other hand, has developed sensory and cognitive activities aimed at those affected by blindness and deafness through using plants, fruits and animals.

Table 4. Characteristics of farms.

\begin{tabular}{|c|c|c|c|c|c|c|c|}
\hline & Farm 1 & Farm 2 & Farm 3 & Farm 4 & Farm 5 & Farm 6 & Farm 7 \\
\hline Year of business start-up & 2018 & 2016 & 2013 & 2013 & 2012 & 2008 & 2015 \\
\hline Province & Ancona & $\begin{array}{l}\text { Pesaro } \\
\text { Urbino }\end{array}$ & Macerata & Ancona & $\begin{array}{l}\text { Pesaro } \\
\text { Urbino }\end{array}$ & $\begin{array}{l}\text { Pesaro } \\
\text { Urbino }\end{array}$ & $\begin{array}{l}\text { Pesaro } \\
\text { Urbino }\end{array}$ \\
\hline Production systems & $\begin{array}{c}\text { Horticulture, } \\
\text { olives and } \\
\text { fruit } \\
\text { growing }\end{array}$ & $\begin{array}{l}\text { Horticulture, } \\
\text { olives and } \\
\text { fruit } \\
\text { growing }\end{array}$ & $\begin{array}{l}\text { Livestock } \\
\text { production } \\
\text { and fruit } \\
\text { growing }\end{array}$ & $\begin{array}{l}\text { Arable crops } \\
\text { and forage } \\
\text { growing, } \\
\text { viticulture }\end{array}$ & Arable crops & $\begin{array}{c}\text { Fruit } \\
\text { growing, } \\
\text { horticulture, } \\
\text { livestock } \\
\text { production }\end{array}$ & $\begin{array}{c}\text { Arable crops, } \\
\text { horticulture, } \\
\text { olive } \\
\text { growing }\end{array}$ \\
\hline Services offered & $\begin{array}{c}\text { Social } \\
\text { inclusion, } \\
\text { work } \\
\text { placement }\end{array}$ & $\begin{array}{l}\text { Rehabilitation: } \\
\text { education } \\
\text { services }\end{array}$ & $\begin{array}{l}\text { Training } \\
\text { internships, } \\
\text { rehabilitation; } \\
\text { educational } \\
\text { services }\end{array}$ & $\begin{array}{c}\text { Agrinido, } \\
\text { educational } \\
\text { and teaching } \\
\text { services }\end{array}$ & $\begin{array}{l}\text { Retail trade } \\
\text { services }\end{array}$ & $\begin{array}{c}\text { Training } \\
\text { internships, } \\
\text { work } \\
\text { inclusion }\end{array}$ & $\begin{array}{l}\text { Work } \\
\text { placement, } \\
\text { social } \\
\text { inclusion }\end{array}$ \\
\hline Model of production & Organic & Organic & Organic & Organic & Organic & $\begin{array}{l}\text { Organic (not } \\
\text { certified) }\end{array}$ & Organic \\
\hline Number of employed & 2 & 3 & 4 & 2 & 20 & $3-5$ & $8-11$ \\
\hline $\begin{array}{l}\text { Subscription to SF regional } \\
\text { list operators (EROAS) }\end{array}$ & YES & YES & YES & YES & NO & YES & NO \\
\hline
\end{tabular}

In addition, it is interesting to highlight how the beneficiaries (the mentally disadvantaged, children, the elderly, disabled people, prisoners, minors and adults with addiction problems) are differentiated among the different experiences, and how SF activities are aimed at all kinds of people. Moreover, those involved do not always belong to the categories identified by the legislation of the Marche region through pilot experiences concerning rural child care and active longevity workshop. In the experiences we examined, the mentally disadvantaged turn out to be most involved, whereas the pilot projects focus mainly on children and the elderly. In this heterogeneous picture, what connects is the path of personal and professional growth that the beneficiaries are embarked on, so that their skills of self-management and recovery can be developed through direct contact with nature and animals.

According to the theoretical model outlined in the introduction concerning three different modalities of interaction between social and agriculture worlds, Farm 4 belongs in the first category. In its experience, the beneficiaries are not employed in the production system, but some areas of the farm are dedicated to educational and rehabilitation activities and, in this case, to a kindergarten. Farm 5 and Farm 7 belong in the third category, because they are social agricultural cooperatives initiated with the aim of actively employing disadvantaged people in their production system. In this category, the social and the agricultural aspects are close partners and collaborate to reach the shared target, namely, to increase social inclusion and integrate disadvantaged people in the community. For example, Farm 5 has started a project named Emporio AE, that is, a network of cooperatives, associations and organic farms which uses a bottom-up approach to build a sustainable and fair market operating within the territory of the Province of Pesaro Urbino, by valuing people's relationships and raising consumer awareness.

Farm 2 belongs in the second category, since the farm has drawn up an agreement with a social cooperative in the area to carry out social farming activities and it involves disabled people in simple farm activities, such as looking after the chicken coop and egg collection, horticulture and basketry. Farm 1 also belongs in this second category and has taken part in several projects provided by the university and public bids. 
Table 5. Implementation or direct knowledge of SF experiences and typology of SF.

\begin{tabular}{|c|c|c|c|c|c|c|c|}
\hline Name & Farm 1 & Farm 2 & Farm 3 & Farm 4 & Farm 5 & Farm 6 & Farm 7 \\
\hline Social farming activities & $\begin{array}{l}\text { YES-different } \\
\text { projects of SF mainly } \\
\text { to offset periods } \\
\text { when farming stops }\end{array}$ & $\begin{array}{l}\text { YES-thanks to the } \\
\text { conversion of an } \\
\text { unused building } \\
\text { into a day care } \\
\text { centre for the } \\
\text { mentally } \\
\text { disadvantaged }\end{array}$ & $\begin{array}{l}\text { YES-rehabilitation } \\
\text { activities for } \\
\text { disabled people } \\
\text { with the support of } \\
\text { their donkeys }\end{array}$ & $\begin{array}{l}\text { YES_Agrinido } \\
\text { Project }\end{array}$ & $\begin{array}{l}\text { YES—Emporio ae } \\
\text { project }\end{array}$ & $\begin{array}{l}\text { YES—several SF } \\
\text { projects }\end{array}$ & $\begin{array}{l}\text { YES—Several SF } \\
\text { projects }\end{array}$ \\
\hline Main activities & $\begin{array}{c}\text { Rehabilitation } \\
\text { activities; } \\
\text { biodynamic } \\
\text { educational projects; } \\
\text { work placement }\end{array}$ & $\begin{array}{l}\text { Educational and } \\
\text { rehabilitation } \\
\text { activities with the } \\
\text { support of animals; } \\
\text { gardening; basketry } \\
\text { and weaving } \\
\text { activities }\end{array}$ & $\begin{array}{c}\text { Assisted } \\
\text { rehabilitation } \\
\text { therapy with the } \\
\text { support of animals; } \\
\text { work placement; } \\
\text { educational } \\
\text { activities }\end{array}$ & $\begin{array}{c}\text { Outdoor early } \\
\text { childhood education }\end{array}$ & $\begin{array}{l}\text { Production and } \\
\text { retail }\end{array}$ & $\begin{array}{l}\text { Educational farm, } \\
\text { apiculture, active } \\
\text { longevity, work } \\
\text { placement, } \\
\text { educational } \\
\text { activities }\end{array}$ & $\begin{array}{l}\text { Production and } \\
\text { retail, environmental } \\
\text { education work } \\
\text { placement, } \\
\text { therapeutic activities } \\
\text { with vegetable } \\
\text { garden }\end{array}$ \\
\hline Beneficiaries & $\begin{array}{c}\text { Mentally } \\
\text { disadvantaged; } \\
\text { children; teenagers; } \\
\text { the elderly; } \\
\text { prisoners and people } \\
\text { with addictions }\end{array}$ & $\begin{array}{c}\text { Mentally } \\
\text { disadvantaged }\end{array}$ & $\begin{array}{c}\text { Mentally } \\
\text { disadvantaged; } \\
\text { children; teenagers; } \\
\text { adults with } \\
\text { addiction problems }\end{array}$ & Children aged 0-3 & $\begin{array}{c}\text { Mentally } \\
\text { disadvantaged }\end{array}$ & $\begin{array}{c}\text { Mentally } \\
\text { disadvantaged, } \\
\text { children, the elderly }\end{array}$ & $\begin{array}{l}\text { Disabled people, } \\
\text { prisoners, minors } \\
\text { and adults with } \\
\text { addiction problems }\end{array}$ \\
\hline Project duration & Ongoing since 2018 & Ongoing since 2016 & Ongoing since 2013 & Ongoing since 2014 & Ongoing since 2010 & Ongoing since 2008 & Ongoing since 2015 \\
\hline Typology of SF & Second & First & Second & First & Third & Second & Third \\
\hline Strengths & $\begin{array}{l}\text { Concrete support to } \\
\text { disadvantaged } \\
\text { people }\end{array}$ & $\begin{array}{l}\text { Social inclusion of } \\
\text { people with } \\
\text { disabilities }\end{array}$ & $\begin{array}{l}\text { Labour inclusion of } \\
\text { people with } \\
\text { disabilities }\end{array}$ & $\begin{array}{l}\text { Farm as setting of } \\
\text { educational } \\
\text { activities plus } \\
\text { diversification of } \\
\text { farm activities }\end{array}$ & $\begin{array}{l}\text { Innovative } \\
\text { interaction between } \\
\text { local farmers and } \\
\text { public services }\end{array}$ & $\begin{array}{l}\text { Labour inclusion of } \\
\text { people with } \\
\text { disabilities }\end{array}$ & $\begin{array}{c}\text { Development of the } \\
\text { rural areas, setting } \\
\text { SF in public policy } \\
\text { agenda }\end{array}$ \\
\hline Weakness & $\begin{array}{l}\text { Low financial } \\
\text { support }\end{array}$ & $\begin{array}{l}\text { Low financial } \\
\text { support }\end{array}$ & $\begin{array}{l}\text { Focus on regional } \\
\text { pilot projects, } \\
\text { neglecting people } \\
\text { with disabilities } \\
\text { social inclusion } \\
\text { needs }\end{array}$ & $\begin{array}{l}\text { High costs of staff } \\
\text { and management }\end{array}$ & $\begin{array}{l}\text { Low financial } \\
\text { support and limited } \\
\text { to regional pilot } \\
\text { projects }\end{array}$ & $\begin{array}{l}\text { Distance and } \\
\text { diversity between } \\
\text { the social and } \\
\text { agricultural field; } \\
\text { Lack of } \\
\text { communication } \\
\text { between them }\end{array}$ & $\begin{array}{l}\text { Insufficient support } \\
\text { for the viability of } \\
\text { farms; difficulty of } \\
\text { collaboration } \\
\text { between farms and } \\
\text { social cooperatives }\end{array}$ \\
\hline
\end{tabular}


Nearly all the farms interviewed have obtained funds, mainly from public and regional bodies. For example, Farm 3 participated in the RDP, obtaining $40 \%$ of the cost coverage to expand the necessary structures (a sales point, a laboratory and a tasting room), as did Farm 4, which obtained financial aid of $€ 60,000$ to build the structure dedicated to the kindergarten. Funds obtained are mainly of a structural nature. The case of Farm 7 differs in that it gained economic support from private foundations. In contrast, Farm 1 has not obtained any financial support.

All the interviewees agreed about the strengths and weaknesses of SF projects. The main strength pointed out was the direct support given by social agriculture to disadvantaged people. This allows them to have an active role in the community thanks to work inclusive activities. Social agricultural cooperatives all share the common goal of enhancing social inclusion and the reintegration into society of disadvantaged people. Moreover, the interviewees underlined how their passion for the job and human values are the conditions for creating value for all involved, from the beneficiaries to the community.

According to Farm 5 and Farm 6, among the strengths of the projects, it is possible to highlight the creation of relationships between different persons active in the region (institutions, farmers, social cooperatives, consumers) with positive implications also in terms of rural development. SF activities are also an innovative way to mitigate seasonal stop and diversify farming activities, thereby allowing farms to exploit their resources 365 days a year. In addition, farms can expand their target groups towards consumers responsive to social issues.

The main weakness concerns insufficient support from rural policies due to a lack of recognition of the role played by SF. Economic neglect is certainly the most important point of agreement among all the interviewees; financial support is fundamental for the viability of these activities. Since they operate in low value-added sectors and the incomes generated are insufficient to cover the costs and provide the necessary structures, direct support from public bodies is needed. This can be interpreted as a sign of neglect by the regional institutions, which seem to be only focused on its pilot projects, such as the model of Agrinido and the Longevità Attiva. Therefore, it is in this direction that more effort is needed.

Presence on the regional list (EROAS) is a necessary condition but not enough to obtain financial support from the region. Farm 1 failed to get any public financial contributions, even though it had been carrying out different SF projects and it is on EROAS. This restricts the viable management of these activities. Regional funding is mainly of a structural nature and far from the real needs of SF operators, who require more regional presence in support of management and staff costs.

\section{Discussion and Concluding Remarks}

The results of the study confirm the main hypothesis of the research: SF policy and practices might be very heterogeneous, not only in different national contexts, as it has been argued in previous studies, but also within the same national and local level.

The main Italian national regulatory context (Law No. 141/2015) is quite recent and confirms the institutional autonomy of the regions in adopting regulatory and policy measures regarding SF. Consequently, SF policy in Italy is fragmented and highly differentiated at a regional level depending on timeframe, the authorities, activities, personnel and support. Regional differences are rooted in different regional institutional regulatory frameworks.

Moreover, policy analysis shows several different modalities of interaction between social and agricultural aspects: different hybridization of social and agriculture actions that might be interpreted according to the suggested theoretical framework [9]. SF policy regulation in Lombardy, for example, clearly sets two different types of social farming that are coherent with the theoretical framework to be tested-the fattorie erogative as the first SF modality, where the vulnerable are beneficiaries of the services but do not participate in production; and fattorie inclusive, representing the second modality, where the disadvantaged play an active part in agricultural production. In other regional regulatory frameworks, the divisions are not so clear, but as the Marche case study shows, the farms can be just the 
context for social activities such as in the Agrinido and Longevità Attiva (first typology) or the farms can actively involve disadvantaged people in their productivity process (second typology) as part of the local case studies (1-3 and 6). The social cooperative practices represent the third typology, where the farm organizes its activities to actively employ disadvantaged people in order to enhance their social inclusion and integration in the community, as in the local case studies 5 and 7 . The three SF model proposal represents a valid analytical tool to outline the differences in "connective agriculture" [28].

The heterogeneous regulatory context situation can represent a strength (in terms of adapting the regional provisions to the characteristics of the various territories as well as social needs of local communities) but also an obstacle to the development of SF experiences in Italy; for example, the absence, in many regions, of specific support measures for the various SF projects. However, our analysis focused on the policy dimension at the regulatory level, while further studies should be carried out to evaluate effective implementations in all Italian regions, mainly through specific further policy initiatives such as decrees.

In the case study of the Marche region, policies supporting SF are marked by a strong focus on two particular types of initiatives: the Agrinido and the Longevità Attiva. These initiatives have led to a definition of high-quality pilot experiences, but they have struggled to spread within the area [51]. In contrast, for other areas of competence of SF (in particular, socio-working insertion of disadvantaged people and food education), there is a substantial lack of support from regional policies.

The analysis of the case studies of farms highlights a certain diversity, relative to the characteristics of the projects but also to awareness and involvement in SF. The data reveal divergent positions on how the social and the agriculture perspectives integrate. On the one hand, some give more importance to the social value of these activities, whereas others see, in social farming, new ways to diversify income and activities. Social farming is giving a new value to disadvantaged people; this is not simply about a responsibility to help in the community, but rather real alternative working resources. Since the potentialities are many, all the interviewees highlighted several challenges for SF in the future. More integration between the social and agricultural is required to enhance the viability of social farming. The perceptions about opportunities and challenges facing SF differs among the three different categories in the local case studies analyzed. SF, in the first and second typologies, consider social and labor inclusion for people with disabilities as the main strength, while SF in the third typology (social cooperative) highlights the innovative potentiality for rural development. Two farms, the case studies no. 6 and 7, representing second and third typology, stress the difficulties in the relationship between social and agricultural organizations, while all the interviewees struggled to get financial support from public bodies. The respondents in the case studies felt that there was a need for more public support, nevertheless, this aspect brings to light a complex issue concerning the need to evaluate the effectiveness and efficiency of SF policy and practices in Italy to provide social services in rural areas and, more in general, to promote local development models that are sustainable also in economics [6-8].

Nevertheless, the SF boundaries between agriculture and social services are still very blurry in the Italian context: SF is mainly an agriculture and rural development issue, still far away from the welfare and social services network perspective [11]. Further analysis would be necessary, also at European level, to an in depth investigation of the relationship between agriculture and welfare policy and, therefore, on integrated public policy for the promotion of rural welfare development. Now, the SF Italian regulatory context is strongly characterized by the dominant perspective of farming multi-functionality, with low attention on highlighting the added value of SF for the society [52]. There is a lack of analysis on the value of SF activities in terms of services that can be complementary to already existing social services, or totally new, such as the potentialities of domiciliary services in farming context, or any other social services offered within the farming framework to overcome the gap in the supply of local social services. Social services within a SF framework might also bring important opportunities for creating qualified jobs in rural areas. 
In the last years, many farms and social cooperatives have diversified their activities, offering projects able to respond to the needs of local communities and also to the demands of an increasing number of aware consumers [53]. These are experiences initiated from the bottom, also in the context of projects in the (co)building of alternative exchange mechanisms to those of modern supply chains [54]. In this regard, the study should be further developed in the direction of a theoretical and methodological scheme for assessing the effective impact of SF projects, from the point of view of businesses and social workers, also by defining an indicator's framework to evaluate non-commodity output $[55,56]$.

More in general, this study intends to contribute to academic research on SF as part of the broader debate on the various dimensions of sustainability, especially with reference to rural/marginal areas, leading to a wider reflection, especially in relation to the following. Firstly, it is necessary to highlight the multiplicity of possible interactions between the social and agricultural in the experiences of SF [9], which widen the range of SF initiatives where the social function is directly connected to agricultural activity, because the service can fully express and take advantage of its usefulness and potential through involvement in the farming practices of the beneficiaries [57].

Furthermore, SF is part of the ecological conversion to organic farming, contributing, as well to the improvement of the environment (improvements in biodiversity and soil fertility, higher water holding capacity, mitigation of the greenhouse effect, and adaptation to climate change), and the decrease in health risk [58-63]. This aspect is particularly important in SF experiences, where organic farming assumes a fundamental role in protecting the vulnerable (mentally disadvantaged, children, teenagers, etc.), reducing their exposure to chemical pesticides. For the firms, organic production also offers a further possibility for differentiation and improvement in products [64-66], also through use in public canteens, promotion in Alternative Food Networks or the creation of dedicated platforms [67-69].

Social farming is, therefore, a phenomenon capable of activating significant synergies for the development of many areas increasingly at risk of marginalization, providing effective answers to the demand for public services and, at the same time, possibilities in the construction of rural welfare and the creation of income and employment at farm level.

Author Contributions: Conceptualization, A.G. and E.V.; methodology, A.G. and E.V.; validation, A.G and E.V.; formal analysis, M.M.; investigation, M.M.; resources, E.V.; data curation, A.G.; writing-original draft preparation, M.M.; writing-review and editing, A.G. and E.V.; supervision, E.V.; project administration, A.G. This manuscript is a collaboration. However, A.G. is responsible for paragraph 1 and 2; M.M. and A.G. for paragraphs 3.1.; M.M. and E.V. for paragraph 3.2. Paragraph 4 should be attributed to A.G. and E.V. All authors have read and agreed to the published version of the manuscript.

Funding: This research received no external funding.

Acknowledgments: In this section you can acknowledge any support given which is not covered by the author contribution or funding sections. This may include administrative and technical support, or donations in kind (e.g., materials used for experiments). (to be completed).

Conflicts of Interest: The authors declare no conflict of interest.

\section{References}

1. Phillips, W.; Lee, H.; James, P.; Ghobadian, A.; O’Regan, N. Social innovation and social entrepreneurship: A systematic review. Group. Organ. Manag. 2015, 40, 428-461. Available online: http://eprints.uwe.ac.uk/24436 (accessed on 13 February 2020). [CrossRef]

2. OECD. Multifunctionality: Towards an Analytical Framework; OECD Publishing: Paris, France, 2001. Available online: https://doi.org/10.1787/9789264192171-en (accessed on 13 February 2020).

3. Henke, R. Verso il Riconoscimento di Una Agricoltura Multifunzionale. Teorie, Politiche, Strumenti; INEA: Rome, Italy, 2004.

4. Wilson, G.A. Multifunctional Agriculture: A Transition Theory Perspective; CABI: Wallingford, UK, 2007.

5. Renting, H.; Rossing, W.A.H.; Groot, J.C.J.; Van der Ploeg, J.D.; Laurent, C.; Perraud, D.; Stobbelaar, D.J.; Van Ittersum, M.K. Exploring multifunctional agriculture. A review of conceptual approaches and prospects for an integrative transitional framework. J. Environ. Manag. 2009, 90 (Suppl. 2), S112-S123. [CrossRef] [PubMed] 
6. Di Iacovo, F.; Fumagalli, S.; Sabbadini, M.; Venturelli, S. La co-Produzione Innovativa in Agricoltura Sociale: Sentieri, Organizzazione e Collaborazioni Nelle Nuove Reti Locali. In Proceedings of the Annual Scientific Colloquium on Social Enterprise, Torino, Italy, 1-4 July 2013; IrisNetwork: Torino, Italy, 2013.

7. Sturla, A.; Viganò, E.; Viganò, L. The Organic Districts in Italy. An Interpretative hypothesis in the Light of the Common Pool Resources Theory. Food Econ. 2019, 21, 429-458. [CrossRef]

8. Polman, N.; Poppe, K.J.; van der Schans, J.-W.; van der Ploeg, J.D. Nested markets with common pool resources in multifunctional agriculture. Riv. Econ. Agrar. 2010, 65, 295-318.

9. Genova, A. Sociologia strumentale e riflessiva nella costruzione del welfare rurale. Sociol. Urban. Rural. 2020, 123, accepted to be published.

10. Reterurale. La Banca Dati Degli Indicatori di Contesto 2014-2020. Available online: https://www.reterurale. it/indicatoricontesto (accessed on 3 April 2020).

11. Genova, A.; Nothdurfter, U.; Viganò, F. Agricoltura Sociale tra Politiche di Sviluppo Rurale e Politiche di Welfare; BU Press: Bozen, Italy, 2020; (accepted to be published).

12. Giarè, F.; Macrì, M.C.; Durastanti, F.; Finuola, R. La Valutazione Delle Azioni Innovative di Agricoltura Sociale. Sistema Della Conoscenza; Quaderni INEA: Roma, Italia, 2013.

13. Reterurale. Rapporto Sull'Agricoltura Sociale in Italia. Available online: http://www.reterurale.it/flex/cm/ pages/ServeBLOB.php/L/IT/IDPagina/18108 (accessed on 30 March 2020).

14. Ferrera, M. Le Politiche Sociali (Social Policies); Il Mulino: Bologna, Italia, 2006.

15. Van der Ploeg, J.D.; Renting, H.; Brunori, G.; Knickel, K.; Mannion, J.; Marsden, T.; De Roest, K.; Sevilla-Guzmán, E.; Ventura, F. Rural development: From practices and policies towards theory. Sociol. Rural. 2000, 40, 391-408. [CrossRef]

16. Van der Ploeg, J.D. The New Peasantries: Struggles for Autonomy and Sustainability in an ERA of Empire and Globalization; Earthscan: London, UK, 2009.

17. Di Iacovo, F.; O'Connor, D. Supporting Policies for Social Farming in Europe Progressing Multifunctionality in Responsive Rural Areas; ARSIA: Firence, Italy, 2009.

18. Di Iacovo, F.; Moruzzo, R.; Rossignoli, C.; Scarpellini, P. Transition management and social innovation in rural areas: Lessons from social farming. J. Agric. Educ. Ext. 2014, 20, 327-347. [CrossRef]

19. Hassink, J.; Van Dijk, M. Farming for Health: Green-Care Farming Across Europe and the United States of America; Springer Science \& Business Media: Berlin, Germany, 2006; Volume 13.

20. Hassink, J.; Grin, J.; Hulsink, W. Enriching the multi-level perspective by better understanding agency and challenges associated with interactions across system boundaries. The case of care farming in the Netherlands: Multifunctional agriculture meets health care. J. Rural Stud. 2018, 57, 186-196. [CrossRef]

21. O'Connor, D.; Lai, M.; Watson, S. Overview of Social Farming and Rural Development Policy in Selected EU Member States; NRN Joint Thematic Initiative on Social Farming; European Network for Rural Development European Communities: Brussels, Belgium, 2010.

22. De Vivo, C.; Ascani, M.; Gaito, M. Social Farming and inclusion in EU ESI Funds programming. Ital. Rev. Agric. Econ. 2019, 74, 53-60.

23. Tulla, A.F.; Vera, A.; Badia, A.; Guirado, C.; Valldeperas, N. Rural and regional development policies in Europe: Social farming in the common strategic framework (HORIZON 2020). J. Urban Reg. Anal. 2014, 6, 35.

24. García-Llorente, M.; Rossignoli, C.M.; Di Iacovo, F.; Moruzzo, R. Social farming in the promotion of social-ecological sustainability in rural and periurban areas. Sustainability 2016, 8, 1238. [CrossRef]

25. Garcia-Llorente, M.; Rubio-Olivar, R.; Gutierrez-Briceno, I. Farming for life quality and sustainability: A literature review of green care research trends in Europe. Int. J. Environ. Res. Public Health 2018, 15, 1282. [CrossRef] [PubMed]

26. Hassink, J.; Hulsink, W.; Grin, J. Farming with care: The evolution of care farming in the Netherlands. NJAS-Wageningen. J. Life Sci. 2014, 68, 1-11. [CrossRef]

27. Di Iacovo, F.; Moruzzo, R.; Rossignoli, C.M.; Scarpellini, P. Measuring the effects of transdisciplinary research: The case of a social farming project. Futures 2016, 75, 24-35. [CrossRef]

28. Leck, C.; Evans, N.; Upton, D. Agriculture-Who cares? An investigation of 'care farming'in the UK. J. Rural Stud. 2014, 34, 313-325. [CrossRef]

29. Scuderi, A.; Timpanaro, G.; Cacciola, S. Development policies for social farming in the EU-2020 strategy. Calitatea 2014, 15, 76 . 
30. Barnaud, C.; Couix, N. The multifunctionality of mountain farming: Social constructions and local negotiations behind an apparent consensus. J. Rural Stud. 2020, 73, 34-45. [CrossRef]

31. Brites, C.; Miguéns, F.; Santos, D.; Veríssimo, M.; Moreira, P.M. Green care and social farming: Future perspectives in Portugal. In Proceedings of the International Conference on Multifunctional Agriculture and Urban-Rural Relations-Agriculture in an Urbanized Society, Wageningen, The Netherlands, 1-4 April 2012; pp. 1-4.

32. Guirado, C.; Valldeperas, N.; Tulla, A.F.; Sendra, L.; Badia, A.; Evard, C.; Cebollada, À.; Espluga, J.; Imma Pallarès, I.; Vera, A. Social farming in Catalonia: Rural local development, employment opportunities and empowerment for people at risk of social exclusion. J. Rural Stud. 2017, 56, 180-197. [CrossRef]

33. Matysiak, I.; Michalska, S. Social farming: A new model of dealing with ageing in rural areas in Poland? Sociol. Politiche Soc. 2016, 19, 65-82. [CrossRef]

34. Di Iacovo, F.; Moruzzo, R.; Rossignoli, C. Social farming and policies in Tuscany, between social innovation and path dependency. Ital. Rev. Agric. Econ. 2018, 73, 107-131.

35. Di Iacovo, F.; Moruzzo, R.; Rossignoli, C.M. Collaboration, knowledge and innovation toward a welfare society: The case of the Board of Social Farming in Valdera (Tuscany), Italy. J. Agric. Educ. Ext. 2017, 23, 289-311. [CrossRef]

36. Dell'Olio, M.; Hassink, J.; Vaandrager, L. The development of social farming in Italy: A qualitative inquiry across four regions. J. Rural Stud. 2017, 56, 65-75. [CrossRef]

37. Bassi, I.; Nassivera, F.; Piani, L. Social farming: A proposal to explore the effects of structural and relational variables on social farm results. Agric. Food Econ. 2016, 4, 13. [CrossRef]

38. Papaleo, A.; Ricciardi, G. L'agricoltura Sociale Nella Normativa Regionale Italiana; CREA: Rome, Italy. Available online: https://www.reterurale.it/flex/cm/pages/ServeBLOB.php/L/IT/IDPagina/20502 (accessed on 29 May 2020).

39. Fairclough, N. Critical Discourse Analysis: The Critical Study of Language; Routledge: London, UK, 2013.

40. Gee, J.P.; Handford, M. The Routledge Handbook of Discourse Analysis; Routledge: London, UK, 2012.

41. Genova, A.; Palazzo, F. Il Welfare Nelle Marche; Carocci: Rome, Italy, 2008.

42. Yin, R. Case Study Research, Design and Methods, 2nd ed.; Sage: London, UK, 1994.

43. Patton, M.Q. Qualitative Research E Evaluation Methods; Sage: London, UK, 2001.

44. Miles, M.B.; Huberman, A.M. Qualitative Data Analysis: An Expanded Sourcebook; Sage: London, UK, 1994.

45. Visconti, G. L'impresa di Agricoltura Sociale Introdotta Dalla Legge $\mathrm{n}^{\circ} 141$ del 2015. Available online: https://www.diritto.it/l-impresa-di-agricoltura-sociale-introdotta-dalla-legge-n-141-del-2015/ (accessed on 10 March 2020).

46. ISMEA. Multifunzionalità Agricola e Agriturismo. Scenario e Prospettive; Rapporto 2017; ISMEA: Rome, Italy, 2017. Available online: http://www.ismea.it/flex/cm/pages/ServeBLOB.php/L/IT/IDPagina/10200 (accessed on 10 February 2020).

47. Regione Lombardia. Available online: https://www.regione.lombardia.it/wps/portal/istituzionale/HP/ DettaglioRedazionale/servizi-e-informazioni/cittadini/agricoltura/fattorie-didattiche-e-sociali/fattoriesociali-in-lombardia/fattorie-sociali-in-lombardia (accessed on 20 April 2020).

48. Regione Marche. Il Format Agrinido di Qualità. Progetto sperimentale Agrinido di Qualità. 2014. Available online: http://www.agri.marche.it/Aree\%20tematiche/agrinido/BROCHURE_AGRINIDO_DEF.pdf (accessed on 12 May 2020).

49. Regione Marche. DRG 336/2016: DGR 1130/2015. Approvazione “Modello del Laboratorio di Longevità Attiva in Ambito Della Regione Marche". Available online: http://www.norme.marche.it/Delibere/2016/ DGR0336_16.pdf (accessed on 12 May 2020).

50. Regione Marche. Available online: https://www.regione.marche.it/Regione-Utile/Agricoltura-SviluppoRurale-e-Pesca/Agricoltura-sociale\#OrtoIncontro (accessed on 12 May 2020).

51. Genova, A.; Moretti, C.; Viganò, E. Gli Agrinido Nelle Marche: Esperienze di Innovazione. In Scuola e Innovazione Culturale Nelle Aree Interne; Luigi, D., Tantillo, F., Eds.; Loescher Editore: Torino, Italy, 2019; Volume 50, pp. 78-87.

52. Cirulli, F.; Berry, A.; Borgi, M.; Francia, N.; Alleva, E. L'agricoltura Sociale Come Opportunità di Sviluppo Rurale Sostenibile: Prospettive di Applicazione Nel Campo Della Salute Mentale; Istituto Superiore di Sanità: Rome, Italy, 2011. Available online: http://old.iss.it/binary/neco/cont/ISTISAN_11_29_web.pdf (accessed on 11 June 2020). 
53. Viganò, E.; Antonelli, G.; Bischi, G.I.; Tramontana, F. Consumo e consumatori di prodotti alimentari nella società postmoderna. Econ. Agro-Aliment. 2015, 17, 59-80. [CrossRef]

54. Mariani, A.; Viganò, E. Il Commercio equo: Un modello replicabile per lo sviluppo sostenibile. Riv. Di Studi Sulla Sostenibilità 2013, 1, 149-161. [CrossRef]

55. Madureira, L.; Rambonilaza, T.; Karpinski, I. Review of methods and evidence for economic valuation of agricultural non-commodity outputs and suggestions to facilitate its application to broader decisional contexts. Agric. Ecosyst. Environ. 2007, 120, 5-20. [CrossRef]

56. Fagioli, F.F.; Rocchi, L.; Paolotti, L.; Słowiński, R.; Boggia, A. From the farm to the agri-food system: A multiple criteria framework to evaluate extended multi-functional value. Ecol. Indic. 2017, 79, 9-102. [CrossRef]

57. Senni, S. L'agricoltura sociale tra welfare e mercato. In Agricoltura Sociale e Biologica Strumento del Welfare Partecipativo; Ciaperoni, A., Ed.; AIAB: Rome, Italy, 2008.

58. Tuomisto, H.L.; Hodge, I.D.; Riordan, P.; Macdonals, D.W. Does organic farming reduce environmental impacts?-A meta-analysis of European research. J. Environ. Manag. 2012, 112, 309-320. [CrossRef]

59. Bavec, M.; Bavec, F. Impact of Organic Farming on Biodiversity. In Biodiversity in Ecosystems, Linking Structure and Function; Blanco, J.A., Ed.; IntechOpen: London, UK, 2015; pp. 185-202. [CrossRef]

60. European Parliament. Human Health Implications of Organic Food and Organic Agriculture; European Parliamentary Research Service, Scientific Foresight Unit, PE 581.922: Brussels, Belgium, 2016. Available online: http://www.europarl.europa.eu/RegData/etudes/STUD/2016/581922/EPRS_STU(2016)581922_EN.pdf (accessed on 18 April 2020).

61. Reganold, J.; Wachter, J. Organic agriculture in the twenty-first century. Nat. Plants 2016, 2, 15221. [CrossRef]

62. Baudry, J.; Assmann, K.E.; Touvier, M.; Allès, B.; Seconda, L.; Latino-Martel, P.; Ezzedine, K.; Galan, P.; Hercberg, S.; Lairon, D.; et al. Association of Frequency of Organic Food Consumption with Cancer Risk. Findings From the NutriNet-Santé Prospective Cohort Study. JAMA Intern. Med. 2018, 178, 1597-1606. [CrossRef]

63. Skinner, C.; Gattinger, A.; Krauss, M.; Krause, H.M.; Mayer, J.; van der Heijden, H.-M.; Mäder, P. The impact of long-term organic farming on soil-derived greenhouse gas emissions. Sci. Rep. 2019, 9, 1-10. [CrossRef] [PubMed]

64. Gomiero, T.; Pimentel, D.; Paoletti, M. Environmental Impact of Different Agricultural Management Practices: Conventional vs. Organic Agriculture Critical Reviews. Plant Sci. 2011, 30, 95-124. [CrossRef]

65. Rodale Institute. The Farming Systems Trial Celebrating 30 Years; Rodale Institute: Kutztown, PA, USA, 2015. Available online: https://rodaleinstitute.org/wp-content/uploads/fst-30-year-report.pdf (accessed on 10 June 2019).

66. FAO; WHO. Sustainable Healthy Diets-Guiding Principles; FAO: Rome, Italy; WHO: Geneva, Svitzerland, 2019. Available online: http://www.fao.org/documents/card/en/c/ca6640en/ (accessed on 7 January 2020).

67. Viganò, E.; Mariani, A.; Taglioni, C.; Torquati, B. Consumatori e canali alternativi per il biologico. Il caso del Gruppo Organizzato di Domanda e Offerta di AIAB-Umbria. Econ. Agroaliment. 2012, 14, 173-194. [CrossRef]

68. Blasi, G.; Caruso, A.; Viganò, E. Progettazione partecipata di una mensa scolastica sostenibile mediante lo sviluppo di un Business Model Canvas. Econ. Agroaliment. 2016, 3, 319-344. [CrossRef]

69. Torquati, B.; Viganò, E.; Taglioni, C. Construction of Alternative Food Networks for organic products: A case study of "Organized Groups of Supply and Demand". New Medit 2016, 15, 53-62.

(C) 2020 by the authors. Licensee MDPI, Basel, Switzerland. This article is an open access article distributed under the terms and conditions of the Creative Commons Attribution (CC BY) license (http://creativecommons.org/licenses/by/4.0/). 